\title{
Výzva k diskusi o muzeích
}

\author{
Michal Stehlík
}

\section{Call for Discussion about Museums}

$\mathrm{V}$ roce 2020 vyšla pod edičním vedením trojice autorů (Jareš, Pýcha, Sixta) publikace Jak vystavujeme soudobé dějiny. Muzeum $v$ diskusi. $\mathrm{V}$ našem muzejním prostředí se jedná o možná první publikační počin podobného druhu, který se snaží jednak mapovat situaci v oblasti soudobých dějin a muzeí, jednak přinášet pohled z praxe - teoretické teze i praktické zkušenosti, a nakonec také zařazovat naše uvažování do mezinárodního kontextu. Všechny tyto přístupy jsou obsaženy na 240 stranách textu, který je editory členěn do tří kapitol. Nejedná se přitom o typ ucelené analytické monografie, autorům je vlastní spíše výzva k diskusi, nastínění konkrétních témat, otevření problému. I to je důvodem, proč by mohly jednotlivé části knihy fungovat i samostatně, takto na jednom prostoru se však doplňují. V samotném úvodu autoři podrobují muzejní instituce jistého zařazení do "souřadnic". Píšou o muzeu jako o budově, archivu, fóru, popisují muzeum též jako politikum, jako pamět, komunitu, školu i památník. Mezi jejich autorské souřadnice poté patří muzeum jako interpretace, turismus i hádanka. Tak jako tak stojí ve středobodu jejich autorského pohledu diskuse, dialog, proto je zde popsána i role muzea jako tématu (výzkumu a reflexe) a souřadnice jsou zakončeny pohledem na muzeum v diskusi. Samozřejmě bychom jistě dokázali najít pro charakteristiku muzejních institucí i mnoho dalších souřadnic, autoři nás tímto však upozorňují především na své vnímání, kterému je vlastní aktivita, kritický přístup a místy proto i logicky zpochybnění některých stereotypů.

prof. PhDr. Michal Stehlík, Ph.D.

Národní muzeum náměstek pro centrální sbírkotvornou a výstavní činnost michal.stehlik@nm.cz ve 23 muzejních institucích, a to jak u těch velkých (Moravské zemské muzeum, Slezské zemské muzeum, Muzeum hlavního města Prahy), tak ve většině „středních". K jednotlivým muzeím přistupuje na základě „muzejní analýzy“, inspirované Joachimem Baurem, konkrétněji pak využívá historickou metodu Thomase Thiemeyera. Ve svém příspěvku postupuje přes pohled na exponáty, aktéry, až ke kontroverzím a modelům vystavování soudobých dějin. Nabízí se nám tak poprvé určité zrcadlo vystavování nejbližší minulosti, samozrejmě limitované kapacitou autora pojmout jen určitou část muzejních expozic a institucí - ale i přesto umožňující jisté zobecňující závěry. $\mathrm{V}$ tomto případě jde o závěrečné (relativně stručné) zamyšlení nad smyslem muzea, jaký mu autor přisuzuje. Zdůrazňuje především dva aspekty - potřebu vystižení jedinečnosti místa na jedné straně a případné zvýraznění obecnějších, univerzálních problémů (na straně druhé). Václav Sixta ve svém příspěvku Muzeum v rekonstrukci přistupuje $\mathrm{k}$ tématu nejprve pohledem na tři vybrané případy - Prácheňské muzeum v Písku, Muzeum Vysočiny Jihlava a Památník II. světové války v Hrabyni. V návaznosti na př́padové studie pak hledá zobecňující pohledy na to, co ovlivňuje proměny muzeí. Jednak je to dědictví minulosti, dále postoj zřizovatele a způsob financování, následně vliv architektů a realizátorských firem. Již z tohoto přehledu je jasné, že tato studie se snaží nahlédnout na velmi praktické aspekty proměn muzeí. Následují závěry - shrnutí proměn českých muzeí po roce 1989 a dále „Návrh periodizace: od doby figurínové po období multimediálních expozic?". Této studii možná trochu chybí zobecňující závěr, stojí tak trochu na půl cesty mezi praktickým popisem a teoretickým zamyšlením. Studie Čeňka Pýchy pracuje na počátku s pojmy jako je pamět’ v muzeu a muzejní 
stroj digitální platformy. Následně rozvijí své pohledy na způsoby prezentace/tematizace $v$ expozicích soudobých dějin, a to za využití konkrétních př́íkladů a definice rolí: hrdinové a oběti (Lidice, heydrichiáda, památníky); rodinné a nostalgické vzpomínání (retromuzeum); globalizace vzpomínání (muzeum komunismu). Jádrem př́spěvku jsou analýzy muzejních expozic, prričemž autor zde osvědčuje svůj prehled jak $\mathrm{v}$ oblasti teoretických konceptů, tak mezioborových přesahů (nová média).

Druhou částí knihy je přepis diskusí, jež autoři organizovali, na několik témat týkajících se fungování muzeí - samozřejmě v kontextu tématu soudobých dějin. Tato část obsahuje diskuse nad tématy: národ $\mathrm{v}$ muzeu; vystavovat kontroverzní dějiny; muzea a historické vzdělávání. Vždy několik pozvaných hostů se vyjadřovalo $\mathrm{k}$ danému tématu pod moderátorským vedením jednoho $\mathrm{z}$ editorů. Přestože přepis podobných diskusí bývá mnohdy velkým editorským úskalím, ne vždy musí takto využité diskuse $\mathrm{v}$ tisku vypadat přesvědčivě a vyrovnaně, $\mathrm{v}$ tomto př́ipadě se to autorům dle mého názoru celkem podařilo. Pro čtenáře jsou diskuse inspirativním pohledem nejen na teoretické přemýšlení o muzeích a jejich roli, ale i z hlediska praktických pohledů aktérů diskusí, včetně tolik důležitého mezinárodního srovnání. Poslední třetí částí jsou pak překlady tř́ textů, jež považují editoři za vhodné a využitelné pro diskusi o soudobých dějinách $\mathrm{v}$ muzeích. Jedná se o text Detlefa Hoffmanna "Jak mohou pamětové stopy pomoci při zkoumání soudobých dějin. Chvála myšlení, které vychází z objektu (2007)“, dále text Ljiljany Radonić „Vizualizace viníků a obětí v postkomunistických muzeích-památnících (2016)“, a nakonec práce „Muzeum jako katalyzátor (2000)" od Barbary Kirshenblatt-Gimblettové. Přestože se jedná o texty $\mathrm{z}$ různých dekád, pro editory představují důležité myšlenkové zdroje právě k prezentovanému tématu. Do českého prostředí tak přinášejí myšlenky, se kterými je doposud (jak si dovoluji tvrdit) seznámena jen hrstka muzejních pracovníků. Kdybych nyní mírně odbočil - tento př́stup autorů je možná dobrou výzvou, abychom se do budoucna pokusili o nějaký systematiččější př́stup $\mathrm{k}$ zahraniční produkci a našli pro překlady klíčových textů nějakou platformu.

Závěr autorů s podtitulem: „muzeum jako tíha, muzeum jako radost" pak poukazuje na obeznámenost autorů se složitým kontextem českého muzejního prostředí, ale na druhé straně také ukazuje jejich zapálení pro tolik potřebný intelektuální pohyb v něm. Pokud bych měl knihu nějak obecně zhodnotit - bezpochyby se jedná o inspirující vklad do př́liš klidných vod našeho uvažování o muzeích a expozicích. At’ to má důvody praktické, intelektuální, generační či jiné - naše muzejní prostředí není prŕliš zvyklé na přemýšlení o nás samých, a pokud ano, nevstupujeme $\mathrm{s}$ tímto přemýšlením do dialogu, diskuse, vzájemné konfrontace (v pozitivním slova smyslu). To se snaží tato publikace změnit. Nemáme sice před sebou nějakou "těžkotonážní" monografii na dané téma - možná ji ale $\mathrm{v}$ tento moment ani nepotřebujeme, ani jí nejsme ještě mocni. Nyní je třeba oživení diskuse, přirozené propojení s celosvětovým kontextem diskuse o kulturním dědictví - a také trochu odvahy $\mathrm{v}$ těmito diskusemi vstupovat do veřejného prostoru. $\mathrm{V}$ tomto ohledu publikace splnila svůj účel - sama je výzvou k diskusi.

JAREŠ, Jakub, PÝCHA, Čeněk, SIXTA, Václav (eds.).: Jak vystavujeme soudobé dějiny. Muzeum v diskusi. Praha: Ústav pro studium totalitních režimů a Nakladatelství Lidové noviny, 2020, 240 s. ISBN 978-80-88292-67-8 (ÚSTR), 978-80-7422-768-4 (NLN). 